\title{
ACCUMULATION AND EXPORT OF MICRONUTRIENTS IN POTATO FERTILIZED WITH ORGANIC-MINERAL FERTILIZER
}

\author{
ACUMULAÇÃO E EXPORTAÇÃO DE MICRONUTRIENTES EM BATATA \\ ADUBADA COM FERTILIZANTE ORGANO-MINERAL
}

\section{Leandro da Silva ALMEIDA ${ }^{1}$; Hamilton Seron PEREIRA ${ }^{2}$; Atalita Francis CARDOSO ${ }^{3}$; Regina Maria Quintão LANA ${ }^{2}$; José Geraldo MAGESTE ${ }^{2}$; Luara Cristina de LIMA ${ }^{1}$; José Magno Queiroz LUZ}

1Doutorando em Agronomia na Universidade Federal de Uberlândia, Uberlândia, MG, Brasil. almeidalean26@gmail.com; 2. Professores Titulares do Instituto de Ciências Agrárias na Universidade Federal de Uberlândia, Uberlândia, MG, Brasil. 3. Professora no Centro Universitário de Goiatuba, Goiatuba, GO, Brasil

\begin{abstract}
The response of potato plants to organo-mineral fertilization is still poorly understood. Hence, the aim of this study was to evaluate absorption and extraction of micronutrients by Agata potato cultivar in winter crop. The experiment was conducted in the municipality of Cristalina, Goiás state, Brazil, from May 26 to August 29 of 2012 . The experimental design was a randomized block with five organo-mineral fertilizer rates, one mineral fertilizer rate (control) and four replications for each treatment. The results demonstrated that the mean total absorption of micronutrients by potato plants for the organo-mineral treatments was higher relative to the mineral treatment; and also that micronutrients were absorbed in the following order: $\mathrm{Fe}>\mathrm{Zn}>\mathrm{Mn}>\mathrm{Cu}>\mathrm{B}$, in relation to total amounts. The average export of micronutrients in potato plants treated with organo-mineral fertilizer was $28 \%, 37 \%, 25 \%, 8 \%$ and $17 \%$ for $\mathrm{Cu}, \mathrm{Fe}, \mathrm{Mn}$ and $\mathrm{Zn}$ (respectively)relative to total amounts absorbed by the plants.
\end{abstract}

KEYWORDS: Nutrients accumulation. Organo-minerals. Solanum tuberosum L.

\section{INTRODUCTION}

Cultivation of potatoes, generally, involves high doses of fertilizers due to the fact that this crop is highly responsive to fertilization (CARDOSO et al., 2007).However, the major concern of potato growers is with the application of macronutrients $(\mathrm{N}, \mathrm{P}, \mathrm{K})$, which can often result in hidden deficiency of micronutrients (SORATTO et al. 2011).In this case, the symptoms of deficiency are not visible; however, micronutrient-deficient crops deliver reduced tuber yield (RAIJ, 2001) of inferior quality (MESQUITA FILHO et al., 2001). Although micronutrients are absorbed at low concentrations, they have equal importance to macronutrients for crop growth (KRKBY; ROMHELD, 2007).

Micronutrient removal by potato plants and fertilization with highly pure mineral materials can lead to micronutrient deficiencies in potatoes after several years of cultivation (FILGUEIRA, 1993). Highly productive cultivars which usually demand high rates of macronutrients further exacerbate this problem (SORATTO et al., 2011). Still, according to Soratto et al. (2011), information regarding uptake and export of micronutrients in potato plants is scarce.

Absorption and extraction of micronutrients depends on external factors, such as cultivation environment, and also internal factors, such as genetic potential and plant age (BERTSCH, 2003).
For that reason, an accurate fertilization program for each cultivar, which optimizes the yield of tubers and prevents over-fertilization, predicates on studies of uptake and export of nutrients (ZOBIOLE et al., 2010).

Potato yields have nearly doubled in recent years in Brazil. They grew from 10 to $15\left(\mathrm{t} \mathrm{ha}^{-1}\right)$ in the 1980 's to 25 to 30 ( $\left.\mathrm{t} \mathrm{ha}^{-1}\right)$ currently, and even above $40\left(\mathrm{t} \mathrm{ha}^{-1}\right)$ in some areas (FAOSTAT, 2016). The highest yields of tubers are obtained on the Brazilian cerrado soils. This fact gives cause for real concern about the need for correction and fertilization of these soils, which are characterized by high fixation of phosphorus (P), magnesium $(\mathrm{Mg})$ and micronutrients (ARIMURA et al., 2007).

It is also known that the purpose of potato growing is to further increase the interaction between factors influencing growth, development and behavior of plants, such as: water, light, $\mathrm{CO}_{2}$, temperature, nutrients and genotype. Among them, fertilization is very important for most Brazilian soils which naturally present low fertility (FONTES; PEREIRA, 2003).

According to Luz et al. (2010), the organomineral fertilizer is more efficient than exclusive fertilization with either organic or mineral materials. It is due to the fact that some of the fractions of the organic matter are humic substances, which enhance and stimulate microbial flora surrounding the root system, facilitate the release of nutrients, increase 
water retention, aeration, nutrient retention, aggregation, and mainly the formation of natural chelates, which directly influence plant nutrition (SOUZA; RESENDE, 2003).

Concerns about the use of organo-mineral fertilizers are high because their effect on the behavior of potato plants is still unknown. Therefore, the aim of this study was to evaluate absorption and removal of micronutrients by Agata potato cultivar in winter crop.

\section{MATERIAL AND METHODS}

The experiment was carried out in the municipality of Cristalina, Goiás state, Brazil on a site granted by the Agricultural Wehrmann ${ }^{\circledR}$ company. The experimental site is located at an altitude around $1189 \mathrm{~m}$, with an average rainfall $1426.3 \mathrm{~mm}$ and average temperature $20.4^{\circ} \mathrm{C}$. The planting of Agata potato cultivar was carried out on
May 26, 2012 and harvested on August 29, 2012, being the winter crop.

The soil was classified as Oxisol with clayey texture (FERREIRA, 2010). The chemical analysis of soil samples extracted from depth of 0$20 \mathrm{~cm}$ (DONAGENA et al., 2011) showed the following results: $\mathrm{pH} 6.40\left(\mathrm{CaCl}_{2}\right), 3.6 \mathrm{~g} \mathrm{dm}^{-}{ }^{3}$ soil organic matter and $50 \mathrm{mg} \mathrm{dm}{ }^{-3} \mathrm{P}$ (resin). The concentration of $\mathrm{K}, \mathrm{Ca}$ and $\mathrm{Mg}$ in the soil was $161.00,5.4$ and $1.0 \mathrm{cmol}_{\mathrm{c}} \mathrm{dm}^{-3}$, repectively, while $\mathrm{H}+\mathrm{Al}$ stayed $2.00 \mathrm{cmol}_{\mathrm{c}} \mathrm{dm}^{-3}$. The micronutrients concentration of $\mathrm{Zn}, \mathrm{Cu}, \mathrm{Fe}, \mathrm{Mn}$ and $\mathrm{B}$ was $12,2.8$, 33, 21,70 and $2.3 \mathrm{cmol}_{\mathrm{c}} \mathrm{dm}^{-3}$, respectively. The base saturation was77\%; andCEC was $8.80 \mathrm{cmol}_{\mathrm{c}} \mathrm{dm}^{-3}$. Thus, the experiment was conducted under conditions of high soil fertility according to the potato crop (MESQUITA et al., 2012).

The experimental design was a randomized block with six rates and four replications in the winter crop (Table 1).

Table 1. Description of the treatments.

\begin{tabular}{lll}
\hline Treatments & $\begin{array}{l}\text { Corresponding percentage } \\
\text { of mineral fertilizer }\end{array}$ & Applied dose $\left(\mathrm{kg} \mathrm{ha}^{-1}\right)$ \\
\hline 1 & & 2.800 \\
2 & $40 \%$ & $1 ., 629.10$ \\
3 & $60 \%$ & 2.443 .60 \\
4 & $80 \%$ & $3,258.20$ \\
5 & $100 \%$ & $4,072.70$ \\
6 & $120 \%$ & $4,887.30$ \\
\hline
\end{tabular}

The experiment consisted of 24 plots, each with six rows $10 \mathrm{~m}$ long spaced $0.8 \mathrm{~m}$ apart, totaling $48 \mathrm{~m}^{2}$ per plot. The evaluations were carried out on two central rows, disregarding two guard rows on each side of the block and a half meter at the ends of each row, totaling $14.4 \mathrm{~m}^{2}$ of evaluation area per plot.

The organo-mineral fertilizer rates were based on Souza \& Lobato (2004) recommendations for mineral fertilizer for high fertility soils. Mineral fertilizer used in this experiment was a 3-32-6 formulation of urea $(45 \% \mathrm{~N})$, triple superphosphate $\left(38 \% \mathrm{P}_{2} \mathrm{O}_{5}\right)$ and potassium chloride $\left(58 \% \mathrm{~K}_{2} \mathrm{O}\right)$.

The organo-mineral fertilizer was based on poultry manure obtained from farms in the region. The production involved initially composting of the organic waste (poultry manure) by means of a controlled aerobic decomposition which lasted, on average, 20 days. To reduce the composting period and accelerate the decomposition process, nutrient cocktails and microorganisms (fungi and bacteria) were used yielding in a few days a stabilized compost. Next, the compost was amended with urea, triple superphosphate and potassium chloride to balance the nutrients, according to nutritional requirements for potato plants, soil fertility and soil nutritional status. Finally, the material was homogenized and pelletized.

The granules possessed a high degree of hardness $\left(8 \mathrm{kgf} \mathrm{cm}^{-2}\right)$, which creates high resistance to breakage and prevents formation of irregular particles. The organic material in the fertilizer: (i) provides physical protection, (ii) forms a porous matrix for the nutrients, and (iii) prevents direct contact of soluble nutrients with the soil. As a result, it promotes lower fixation and leaching losses (TEIXEIRA, 2013).

The chemical characterization of organomineral fertilizer was carried out in the laboratory is presented in Table 2. 
Table 2. Chemical parameters of organo-mineral and mineral fertilizers.

\begin{tabular}{lll}
\hline Nutrients & Organo-mineral & Mineral \\
& $\%$ & \\
\hline Calcium & 2.00 & 1.40 \\
Sulfur & 2.00 & 1.40 \\
Magnesium & 1.50 & 1.10 \\
Boron & 0.20 & 0.14 \\
Copper & 0.10 & 0.07 \\
Manganese & 0.15 & 0.11 \\
Zinc & 0.14 & 0.14 \\
\hline
\end{tabular}

Soil preparation was carried out according to the recommendations for potato crops, with the following tillage operations: plowing, harrowing and furrowing (FILGUEIRA, 2008).

Fertilization was performed manually using hoes to incorporate the fertilizer into soil. Agata type 3 seed tubers $(30-40 \mathrm{~mm}$ diameter) were planted in furrows.

Additional source of macro and micronutrients containing $2.7 \% \mathrm{Ca}, 8.2 \% \mathrm{~S}, 12 \% \mathrm{Zn}$ and $6 \% \mathrm{~B}$ at a dose of $30 \mathrm{~kg} \mathrm{ha}^{-1}$ was applied on all plots at planting, according to Souza \& Lobato (2004) recommendation for potatoes.

Hilling was performed about 30 days after planting in two seasons to stimulate tuberization. Hilling of the winter crop was additionally accompanied by topdressing with $300\left(\mathrm{~kg} \mathrm{ha}^{-1}\right)$ of 20-00-20 formulation, justified by low rainfall during the period.

A central pivot irrigation system was used. The plants received approximately $500 \mathrm{~mm}$ of water during the cycle - a suitable volume for potato crops, which ranges between 450 and $550 \mathrm{~mm}$ (GRIMM et al., 2011).

At harvest, plant samples were done analysis of micronutrients $\mathrm{Cu}, \mathrm{Fe}, \mathrm{Mn}, \mathrm{Zn}$ in leaves, stems and tubers. First, the sample material was washed. Then, the samples were placed in paper bags and taken to a stove with forced air circulation. After drying, the samples were ground in a mill with mesh number 20 . The ground material was analyzed for nutrient content according to the methodology described by Embrapa (1999).

The accumulation of nutrients was calculated by multiplying the quantity of extracted nutrients and dry matter at each stage of plant development in each part of the plant. The nutrient export was obtained from the nutrient accumulation in the tubers at $89 \mathrm{DAP}$, that is, at harvest.

The data were submitted to analysis of variance to verify the existence of differences among the treatments. The comparison of the means for the treatments was carried out using the Scott Knott test at 0.05 significance. The datas for the treatments were submitted to polynomial regression analysis.

\section{RESULTS AND DISCUSSION}

Significant differences among treatments regarding the accumulation of all micronutrients (average) during the potato cycle (Table 3) were observed.

However, the accumulation of micronutrients in stems and leaves was higher for all organo-mineral treatments, except for copper $(\mathrm{Cu})$ where treatment 1 (mineral fertilizer only) was statistically equal to treatment $3(60 \%)$. Boron (B) levels in tubers in treatment 1 was higher than in treatments with organo-mineral fertilizer. Absorption of copper $(\mathrm{Cu})$ and zinc $(\mathrm{Zn})$ in tubers in treatment 1 was statistically equal to treatment 2 (40\%) and treatment 3 (60\%), respectively. Absorption of iron $(\mathrm{Fe})$ in tubers was statistically equal in all treatments, except for treatment 6 $(120 \%)$.

Similar behavior was also observed by Oliveira et al. (2007a), who found better agronomic effect of liquid organo-mineral fertilizers on vegetative growth of lettuce, cultivar Vera, relative to chemical fertilizer. Furthermore, studies carried out by Gonçalves et al. (2007) and Arimura et al. (2007), demonstrated higher yields of potatoes (Atlantic and Agata potatoes cultivars) under organo-mineral fertilizers, which was probably due to better uptake of nutrients.

Luz et al. (2010) found beneficial effect of organo-mineral fertilizer on tomato plants (Débora Pto cultivar), which expressed better production stability and better fruit quality in higher bunches, which according to the literature should occur there wise. According to Luz et al. (2010), the positive effect of the organo-mineral fertilizer is directly linked to organic compounds in its composition which generally optimize the uptake of nutrients.

Studies conducted by Bruno et al. (2007) and Oliveira et al. (2007b) concluded that organo- 
mineral fertilizers improve crop productivity and plant morphological parameters such as length and diameter of roots, and improve the uptake of nutrients by roots (PEDROSA et al., 2007). Kaseker et al. (2014) evaluating the effects of organomineral fertilizers on carrot, also noted increased accumulation of nutrients in plants, even in a highly fertile soil - conditions similar to this study emphasizing, therefore, better efficiency of organomineral fertilizers.

Table 3. Comparative mean extraction of micronutrients by potato plants (Agata cultivar) among treatments with organo-mineral and mineral fertilizer in different parts of plants.

\begin{tabular}{|c|c|c|c|c|c|c|c|c|}
\hline \multirow{2}{*}{$\begin{array}{l}\text { Micro' }^{1} \\
\left(\mathrm{~g} \mathrm{ha}^{-1}\right)\end{array}$} & & \multicolumn{6}{|c|}{ Treatments } & \multirow{2}{*}{$\begin{array}{l}\mathrm{CV} \\
(\%)\end{array}$} \\
\hline & & 1 & 2 & 3 & 4 & 5 & 6 & \\
\hline \multirow{4}{*}{ Boron } & St. $^{2}$ & $22.88 \mathrm{c}$ & $19.15 \mathrm{~d}$ & $32.10 \mathrm{a}$ & $22.80 \mathrm{~b}$ & $22.21 \mathrm{c}$ & $30.32 b$ & 9.14 \\
\hline & Le. $^{3}$ & $16.67 \mathrm{~d}$ & $26.79 \mathrm{~b}$ & $24.12 b$ & $35.68 \mathrm{a}$ & $17.68 \mathrm{c}$ & $34.67 \mathrm{a}$ & 1.87 \\
\hline & Tub. ${ }^{4}$ & $14.76 \mathrm{a}$ & $10.43 b$ & $10.40 \mathrm{~b}$ & $10.45 b$ & $9.36 \mathrm{~b}$ & $11.22 \mathrm{~b}$ & 24.99 \\
\hline & Total & $54.31 \mathrm{~d}$ & $56.38 \mathrm{~d}$ & $66.62 \mathrm{c}$ & $68.93 b$ & $49.24 \mathrm{e}$ & $76.21 \mathrm{a}$ & 4.90 \\
\hline \multirow{4}{*}{ Cupper } & St. & $14.37 \mathrm{~b}$ & $16.96 \mathrm{a}$ & $16.76 a$ & $12.48 \mathrm{c}$ & $6.07 \mathrm{~d}$ & $6.59 \mathrm{~d}$ & 10.93 \\
\hline & Le. & $47.58 b$ & $45.72 \mathrm{c}$ & $46.97 \mathrm{~b}$ & $49.10 \mathrm{a}$ & $35.40 \mathrm{e}$ & $37.68 \mathrm{~d}$ & 2.90 \\
\hline & Tub. & $18.61 \mathrm{a}$ & $20.80 \mathrm{a}$ & $12.39 \mathrm{~b}$ & $9.02 b$ & $9.83 b$ & $10.10 \mathrm{~b}$ & 25.41 \\
\hline & Total & $80.55 b$ & $83.48 \mathrm{a}$ & $76.13 \mathrm{c}$ & $70.60 \mathrm{~d}$ & $51.29 \mathrm{f}$ & $54.37 \mathrm{e}$ & 4.88 \\
\hline \multirow{4}{*}{ Iron } & St. & $574.33 b$ & $322.44 d$ & $345.11 \mathrm{~d}$ & $496.63 c$ & $736.69 a$ & $476.75 c$ & 10.10 \\
\hline & Le. & $1598.70 \mathrm{~d}$ & $1306.11 \mathrm{f}$ & $2007.67 b$ & $2815.34 \mathrm{a}$ & $1479.23 \mathrm{e}$ & $1661.38 \mathrm{c}$ & 1.88 \\
\hline & Tub. & $439.11 \mathrm{a}$ & $523.83 \mathrm{a}$ & $454.51 \mathrm{a}$ & $489.07 \mathrm{a}$ & $372.88 \mathrm{~b}$ & $199.50 \mathrm{~b}$ & 27.41 \\
\hline & Total & $2612.14 \mathrm{c}$ & $\begin{array}{l}2152.37 \\
\mathrm{e}\end{array}$ & $2807.29 b$ & $3801.04 \mathrm{a}$ & $2588.81 \mathrm{c}$ & $2337.63 d$ & 4.14 \\
\hline \multirow{4}{*}{ Manganese } & St. & $22.09 \mathrm{c}$ & $16.91 \mathrm{~d}$ & $23.22 \mathrm{c}$ & $40.19 a$ & $41.73 a$ & $34.50 \mathrm{~b}$ & 8.07 \\
\hline & Le. & $78.51 \mathrm{~d}$ & $81.28 \mathrm{c}$ & $92.78 b$ & $117.49 \mathrm{a}$ & $122.18 \mathrm{a}$ & $81.24 \mathrm{c}$ & 1.40 \\
\hline & Tub. & $11.77 \mathrm{~b}$ & $7.47 \mathrm{c}$ & $9.54 \mathrm{c}$ & $17.08 \mathrm{a}$ & $15.03 \mathrm{a}$ & $16.75 \mathrm{a}$ & 27.22 \\
\hline & Total & $112.37 \mathrm{e}$ & $105.66 \mathrm{f}$ & $125.64 d$ & $174.78 b$ & $178.94 \mathrm{a}$ & $132.49 \mathrm{c}$ & 3.29 \\
\hline \multirow{4}{*}{ Zinc } & St. & $74.62 \mathrm{c}$ & $80.47 b$ & $82.80 \mathrm{~b}$ & $72.82 \mathrm{~b}$ & $64.69 \mathrm{~d}$ & $95.58 \mathrm{a}$ & 10.48 \\
\hline & Le. & $48.17 \mathrm{~d}$ & $49.74 \mathrm{c}$ & $51.31 \mathrm{~b}$ & $67.65 \mathrm{a}$ & $47.40 \mathrm{e}$ & $45.43 \mathrm{f}$ & 1.23 \\
\hline & Tub. & $21.24 \mathrm{a}$ & $19.09 \mathrm{~b}$ & $23.19 \mathrm{a}$ & $11.40 \mathrm{c}$ & $18.13 b$ & $16.71 b$ & 26.65 \\
\hline & Total & $144.04 \mathrm{c}$ & $149.30 \mathrm{~b}$ & $157.30 \mathrm{a}$ & $151.88 \mathrm{~b}$ & $130.23 d$ & $157.72 \mathrm{a}$ & 4.93 \\
\hline
\end{tabular}

Micros: micronutrients; ${ }^{2}$ St.: Steam; ${ }^{3}$ Le.: Leaves; ${ }^{4}$ Tub.: tubers; means followed by the same letter in the line do not differ, by Scott Knott test (1974), p<0.05.

Figure 1 (A, B, C, D and E) shows accumulation curves of micronutrient $(\mathrm{Cu}, \mathrm{Fe}, \mathrm{Mn}$ and $\mathrm{Zn}$, respectively) in potato leaves, stems and tubers during crop cycle in the organo-mineral treatment. Figure 2 shows total absorption curves (sum of stems, leaves and tubercle), during the potato crop cycle.

Maximum accumulation of $B$ in stems was 30,49 $\left(\mathrm{g} \mathrm{ha}^{-1}\right)$ at 74 days after planting (DAP)
(Figure 1A). These results are considerably higher than 8.50 and $10.10\left(\mathrm{~g} \mathrm{ha}^{-1}\right)$, respectively, found by Soratto et al. (2011) for 'Asterix' and 'Mondial' cultivars, which had been the largest accumulation values found by researches working with five potato cultivars treated with mineral fertilizer. Regarding Agata cultivar, Fernandez (2010) found maximum accumulation in stems $4.80\left(\mathrm{~g} \mathrm{ha}^{-1}\right)$ at 71 DAP, working in the municipality of Itaí, São Paulo state. 
The maximum $\mathrm{Cu}$ accumulation in stems was $17.80\left(\mathrm{~g} \mathrm{ha}^{-1}\right)$ at 61 DAP (Figure 1B). Again, this result is different from $1.73\left(\mathrm{~g} \mathrm{ha}^{-1}\right)$ found by Fernandez (2010) for Agata cultivar at 77 DAP. The same author found $5.63\left(\mathrm{~g} \mathrm{ha}^{-1}\right)$ of accumulated $\mathrm{Cu}$ in Mondial potato cultivar.

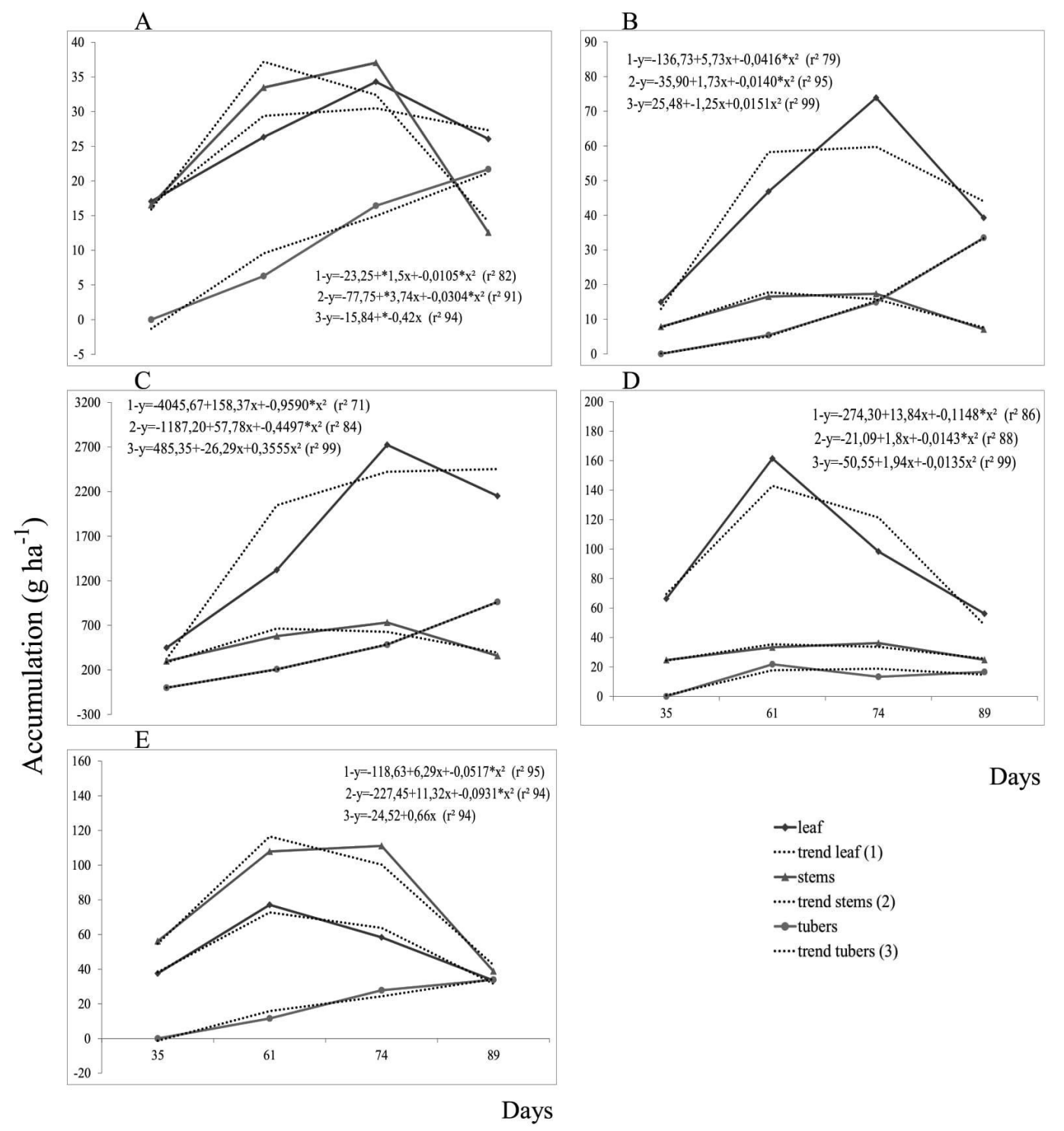

Figure 1. Accumulation curves of nutrients in leaves, stems and tubers of potatoes, 'A': boron (B); 'B':

Copper $(\mathrm{Cu})$; 'C': iron (Fe); 'D' manganese (Mn); 'E' Zinc (Zn).

The maximum $\mathrm{Fe}$ accumulation in stems was $664.10\left(\mathrm{~g} \mathrm{ha}^{-1}\right)$ (Figure 1C) at $61 \mathrm{DAP}$; higher than $131.37\left(\mathrm{~g} \mathrm{ha}^{-1}\right)$ presented by Soratto et al. (2011) for Agata cultivar. The maximum levels of $\mathrm{Mn}$ and $\mathrm{Zn}$ accumulated in stems were 35.50 and $116.57\left(\mathrm{~g} \mathrm{ha}^{-1}\right) 61$ DAP, respectively (Figures 1D and $1 \mathrm{E})$, which are different from $39.80\left(\mathrm{~g} \mathrm{ha}^{-1}\right)$ of $\mathrm{Mn}$ and $18.00\left(\mathrm{~g} \mathrm{ha}^{-1}\right)$ of $\mathrm{Zn}$ observed by Soratto et al. (2011) also for Agata potato cultivar.

The levels of $\mathrm{B}, \mathrm{Cu}, \mathrm{Fe}$ in leaves grew up to 74 DAP (Figures 1A, 1B, 1C); however, $\mathrm{Mn}$ and $\mathrm{Zn}$ foliar levels grew only up to 61 DAP (Figures 1D and $1 \mathrm{E})$, reaching the following maximum levels: $30.50\left(\mathrm{~g} \mathrm{ha}^{-1}\right)$ of B; 59.80( $\left.\mathrm{g} \mathrm{ha}^{-1}\right)$ of $\mathrm{Cu} ; 2453.50(\mathrm{~g}$ $\left.\mathrm{ha}^{-1}\right)$ of Fe; $142.00\left(\mathrm{~g} \mathrm{ha}^{-1}\right)$ of $\mathrm{Mn}$ and $72.00\left(\mathrm{~g} \mathrm{ha}^{-1}\right)$ of $\mathrm{Zn}$. Though, Soratto et al. (2011) observed the following maximum foliar levels for Agata potato cultivar: 19.70; 16.30; 193.00; 359.90 and 42.60(g $\mathrm{ha}^{-1}$ ) of $\mathrm{Cu}, \mathrm{Fe}, \mathrm{Mn}$ and $\mathrm{Zn}$, respectively. Furthermore, the same authors found in their study the following maximum levels of micronutrients in leaves of Mondial potato cultivar: $37.50\left(\mathrm{~g} \mathrm{ha}^{-1}\right)$ of 
B, 24.40 $\left(\mathrm{g} \mathrm{ha}^{-1}\right)$ of $\mathrm{Cu} ; 152.50\left(\mathrm{~g} \mathrm{ha}^{-1}\right)$ of Fe; $490.00\left(\mathrm{~g} \mathrm{ha}^{-1}\right)$ of Mn, and 52.20 $\left(\mathrm{g} \mathrm{ha}^{-1}\right)$ of $\mathrm{Zn}$ in Atlantic potato cultivar.

Except for $\mathrm{Mn}$, micronutrient levels in potato tubers grew until the end of the cycle. However B, $\mathrm{Cu}$ and $\mathrm{Fe}$ accumulation intensified 60 DAP, which can be seen in the accumulation curve (Figures 1A, 1B, 1C). Cabalceta et al. (2005), postulated that $\mathrm{B}$ content in tubers from the beginning of their formation is due to the fact that $\mathrm{B}$

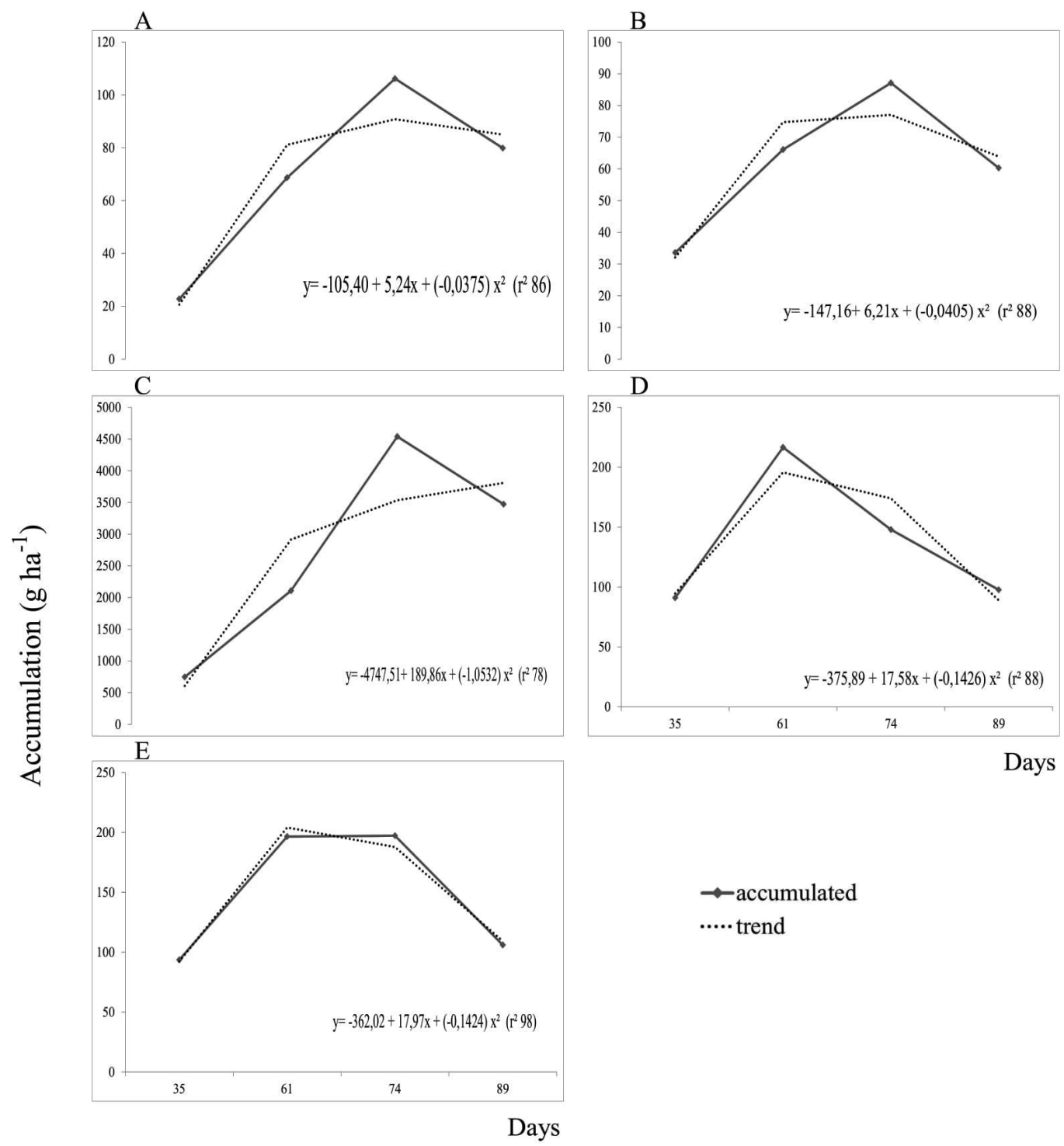

participates in growth and cell division of meristematic tissues, formation of cell walls, and starch translocation from tops to tubers. Thus, as the development of tubers is preceded by intense process of division and cell elongation in the subapical region of stolons, rapid accumulation of B in tubers under formation is common (CABALCETA et al., 2005). 
Absorbed micronutrients relative to total amounts obeyed the following decreasing order: Fe> $\mathrm{Zn}>\mathrm{Mn}>\mathrm{Cu}>\mathrm{B}$ (Figure 2). Soratto et al. (2011) observed similar behavior of micronutrients, with only one difference between $\mathrm{Zn}$ and $\mathrm{Mn}$. However, Yorinori (2003);Cabalceta et al. (2005) and Paul et al. (1986) observed the following sequence: $\mathrm{Fe}>\mathrm{Mn}>\mathrm{Zn}>\mathrm{B}>\mathrm{Cu}$.

The maximum accumulation of micronutrients during the production cycle of Agata potato cultivar was $77.00\left(\mathrm{~g} \mathrm{ha}^{-1}\right) \mathrm{B} ; 90.82\left(\mathrm{~g} \mathrm{ha}^{-1}\right)$ $\mathrm{Cu} ; 3808.08\left(\mathrm{~g} \mathrm{ha}^{-1}\right) \mathrm{Fe} ; 195.90\left(\mathrm{~g} \mathrm{ha}^{-1}\right) \mathrm{Mn}$ and $204.50\left(\mathrm{~g} \mathrm{ha}^{-1}\right) \mathrm{Zn}$. The accumulation of nutrients varies according to productivity, season, environmental conditions, and plant development phase; which occur during vegetative growth and intensify during flowering and formation of fruits and tubers (CARDOSO, 2014).

The accumulation of nutrients in tubers at the end of the cycle corresponds to the total accumulation during the cycle. There was a statistically significant difference among treatments with organo-mineral and mineral fertilizers. However, no significant differences among total yield of tubers per hectare were observed (Table 4).

Table 4. Average export of micronutrient in each treatment, total yield of tubers and average export per ton of tubers.

\begin{tabular}{|c|c|c|c|c|c|c|}
\hline \multirow[t]{2}{*}{ Treatments } & \multicolumn{5}{|c|}{ Export of micronutrients $\left(\mathrm{g} \mathrm{ha}^{-1}\right)$} & \multirow{2}{*}{$\begin{array}{l}\text { Total yield } \\
\left(\mathrm{t} \mathrm{ha}^{-1}\right)\end{array}$} \\
\hline & $\mathrm{B}$ & $\mathrm{Cu}$ & $\mathrm{Fe}$ & Mn & $\mathrm{Zn}$ & \\
\hline 1 & $29.96 \mathrm{c}$ & $45.31 \mathrm{c}$ & $949.08 \mathrm{~b}$ & $12.72 \mathrm{~b}$ & $40.73 \mathrm{~d}$ & $43.12 \mathrm{a}$ \\
\hline 2 & $20.59 \mathrm{a}$ & $47.09 \mathrm{c}$ & $1229.20 \mathrm{c}$ & $7.98 \mathrm{a}$ & $34.99 \mathrm{c}$ & $41.52 \mathrm{a}$ \\
\hline 3 & $22.84 b$ & $35.01 \mathrm{~b}$ & $1221.76 \mathrm{c}$ & $8.63 \mathrm{a}$ & $49.53 \mathrm{e}$ & $42.50 \mathrm{a}$ \\
\hline 4 & $19.74 \mathrm{a}$ & $23,89 \mathrm{a}$ & $1055.44 \mathrm{~b}$ & $27.61 \mathrm{~d}$ & $19.65 \mathrm{a}$ & $42.94 \mathrm{a}$ \\
\hline 5 & $18.75 \mathrm{a}$ & $26.62 \mathrm{a}$ & $915.06 \mathrm{~b}$ & $21.69 \mathrm{c}$ & $32.07 \mathrm{c}$ & $42.50 \mathrm{a}$ \\
\hline 6 & $18.23 \mathrm{a}$ & $23.14 \mathrm{a}$ & $405.47 \mathrm{a}$ & $21.23 \mathrm{c}$ & $25.82 \mathrm{~b}$ & $34.87 \mathrm{a}$ \\
\hline Mean export ${ }^{1}$ & 21.69 & 33.51 & 962.67 & 14.80 & 35.15 & 41.24 \\
\hline \multicolumn{7}{|c|}{ Mean export of nutrients per ton of produced tubers $\left(\mathrm{g} \mathrm{ha}^{-1}\right)$} \\
\hline & $\mathrm{B}$ & $\mathrm{Cu}$ & $\mathrm{Fe}$ & $\mathrm{Mn}$ & $\mathrm{Zn}$ & \\
\hline Export $^{2}$ & 0.53 & 0.81 & 23.34 & 0.36 & 0.85 & \\
\hline
\end{tabular}

${ }^{1}$ Mean export: mean values obtained with regression equation shown in Figure 1; ${ }^{2}$ Export: division of mean export values for organomineral treatment by average yield; Means followed by the same letter in the column do not differ by the Scott Knott test; (1974) at $(\mathrm{p}<0.05)$.

Mean export values of micronutrients in plants treated with the organo-mineral fertilizer in relation to total amounts absorbed by potato plants were: $28 \%, 37 \%, 25 \%, 8 \%$ and $17 \%$ for $\mathrm{Cu}, \mathrm{Fe}, \mathrm{Mn}$ and $\mathrm{Zn}$, respectively. Yorinori (2003) observed that $67 \%$ (72.00 $\mathrm{g} \mathrm{ha}^{-1}$ ) of accumulated B was exported, which is far above the average $21.69\left(\mathrm{~g} \mathrm{ha}^{-1}\right)$ exported by cultivar Agata found in this study (Table 5). However, B export observed by Paula et al. (1986) was $22.00\left(\mathrm{~g} \mathrm{ha}^{-1}\right)$ for Mantiqueira potato cultivar and $12.40\left(\mathrm{~g} \mathrm{ha}^{-1}\right)$ for Achat potato cultivar. Yet, B export found by Soratto et al. (2011) was $43.00\left(\mathrm{~g} \mathrm{ha}^{-1}\right)$ also for Agata cultivar, with similar yield to this study and average $1.17\left[\mathrm{~g}\left(\mathrm{t}^{-1}\right.\right.$ tubers $\left.\left.^{-1}\right)\right]$ de B.

The average amount of exported $\mathrm{Cu}$ was $33.51\left(\mathrm{~g} \mathrm{ha}^{-1}\right)$ (Table 5), very similar to 35.00 ( $\mathrm{g}$ ha $\left.{ }^{1}\right)$ found by Yorinori (2003) in winter crop. However, our result is different from $20\left(\mathrm{~g} \mathrm{ha}^{-1}\right)$ observed by Soratto et al. (2011) for Agata cultivar, and $0.52\left[\mathrm{~g}^{-1} \mathrm{t}^{-1}\right.$ tubers $\left.\left.^{-1}\right)\right]$.

The average amount of exported $\mathrm{Fe}$ in this study was $962.67 \mathrm{~g} \mathrm{ha}^{-1}\left(23.34 \mathrm{~g} \mathrm{t}^{-1}\right)$. It is much higher than $296.00\left(\mathrm{~g} \mathrm{ha}^{-1}\right)$ that corresponding 7.92 $\left(\mathrm{g} \mathrm{ha}^{-1}\right.$ ) observed by Soratto et al. (2011), and also higher than $14.74\left(\mathrm{~g} \mathrm{ha}^{-1}\right)$ obtained by Yorinori (2003).

The average export of Mn was $14.80\left(\mathrm{~g} \mathrm{ha}^{-1}\right)$ (Table 5). It is very close to $16.50\left(\mathrm{~g} \mathrm{ha}^{-1}\right)$ found by Yorinori (2003) in the winter crop, but different from 62.00 $\left(\mathrm{g} \mathrm{ha}^{-1}\right)$ observed by Soratto et al. (2011) for Agata cultivar. Comparing the export per ton of potato tubers, Mn export was $1.67\left(\mathrm{~g} \mathrm{ha}^{-1}\right)$ observed by Soratto et al. (2011) and $0.69\left(\mathrm{~g} \mathrm{t}^{-1}\right)$ observed by Yorinori (2003). Both amounts are higher than 0.39 $\left(\mathrm{g} \mathrm{t}^{-1}\right)$ observed this study (Table 5).

Finally, the average export of $\mathrm{Zn}$ was 35.15 $\left(\mathrm{g} \mathrm{ha}^{-1}\right)$ that corresponding $0.85\left(\mathrm{~g} \mathrm{t}^{-1}\right)$ in the present study (Table 5), which is different from $91.50\left(\mathrm{~g} \mathrm{ha}^{-}\right.$ ${ }^{1}$ ) found by Yorinori (2003), in winter crop, and also different from 63.00 and $24.00\left(\mathrm{~g} \mathrm{ha}^{-1}\right)$ reported by Paula et al. (1986) for Mantiqueira and Achat cultivars, respectively. Further, Zn export observed by Soratto et al. (2011) was $114.00\left(\mathrm{~g} \mathrm{ha}^{-1}\right)$ for Agata cultivar, about $3.07\left[\mathrm{~g}\left(\mathrm{t}^{-1}\right.\right.$ tubers $\left.\left.^{-1}\right)\right]$, which is much higher than in this study. 
As demonstrated in the discussion above, the export of micronutrients, either per hectare or per ton of tubers, vary widely in the literature. It is also important to point out that the comparisons had to be carried out using results obtained in studies with conventional fertilization, i.e. mineral fertilizers. This fact reinforces the importance of intensifying studies with organo-mineral fertilizers to gain better understanding of their behavior in soil-plant system. Thus, more research work under different soil conditions, climate and management systems must be carried out to better recognize the benefits of organo-mineral fertilizers and also their constraints.

\section{CONCLUSIONS}

The mean total absorption of micronutrients by potato plants for the organo-mineral treatments was higher than for the mineral treatment.

Micronutrient absorption in relation to total amounts obeyed the following order $\mathrm{Fe}>\mathrm{Zn}>\mathrm{Mn}>$ $\mathrm{Cu}>\mathrm{B}$, at amounts: $3808.08 ; 204.50 ; 195.90 ; 90.82$ and $77.00\left(\mathrm{~g} \mathrm{ha}^{-1}\right)$, respectively.

The average export of micronutrients for the organo-mineral treatments relative to total amounts of micronutrients absorbed by potato plants were: $28 \%, 37 \%, 25 \%, 8 \%$ and $17 \%$ for $\mathrm{Cu}, \mathrm{Fe}, \mathrm{Mn}$ and $\mathrm{Zn}$, respectively.

RESUMO: A resposta das plantas de batata à adubação organo-mineral ainda é pouco conhecida. Assim, o objetivo deste estudo foi avaliar a absorção e extração de micronutrientes por cultivar Agata de batata na safra de inverno. O experimento foi conduzido no município de Cristalina, Goiás, Brasil, de 26 de maio a 29 de agosto de 2012 . O delineamento experimental foi um bloco casualizados com cinco doses de fertilizantes organo-minerais, uma dose mineral de fertilizante (controle) e quatro repetições para cada tratamento .Os resultados demonstraram que a absorção total média de micronutrientes por plantas de batata para os tratamentos organo-minerais foi maior em relação ao tratamento mineral, e também que os micronutrientes foram absorvidos na seguinte ordem: $\mathrm{Fe}>\mathrm{Zn}>\mathrm{Mn}>\mathrm{Cu}>\mathrm{B}$, em relação às quantidades totais. A exportação média de micronutrientes em plantas de batata tratadas com adubo organo-mineral foi de $28 \%, 37 \%$, $25 \%, 8 \%$ e $17 \%$ para $\mathrm{Cu}, \mathrm{Fe}, \mathrm{Mn}$ e $\mathrm{Zn}$ (respectivamente) em relação às quantidades totais absorvidas pelas plantas.

PALAVRAS-CHAVE: Acumulação de nutrientes. Organo-minerais. Solanum tuberosum.

\section{REFERENCES}

ARIMURA, N. T.; ARREON, R.; LUZ, J. M. Q.; GUIRELLI SILVA, P. A. R.; SILVA, M. A. D. Influência da aplicação de produtos organomineraisAminoagro na produção de batata, cv. Ágata. PaperpresentedIn: ENCONTRO NACIONAL DA PRODUÇÃO E ABASTECIMENTO DE BATATa (Holambra, Brazil, ABBA), 2007.

ALVARADO, A.; ITURRIAGA, I.; SMYTH, J. T.; UREÑA, J. M.; PORTUGUEZ, E. Efecto de lafertilización com fósforo sobre elrendimiento y laabsorción de nutrimentos de la papa enunandisol de Juan Viñas, Costa Rica. Agron. Costarricense, v. 33, p. 45-61, 2009.

BERTSCH, F. 2003. Absorción de nutrimentos por los cultivos, 1 ed (San José, Costa Rica: ACCS), pp. 307.

BRUNO R. L. A.; VIANA, J. S.; SILVA, F. V.; BRUNO, G. B.; MOURA, M. F. Produção e qualidade de sementes e raízes de cenoura cultivada em solo com adubação orgânica e mineral. Horticultura Brasileira, v. 25, p. 170-174, 2007. https://doi.org/10.1590/S0102-05362007000200008

CABALCETA, G.; SALDIAS, M.; ALVARADO, A. Absorción de nutrientes enel cultivar de papa MNF-80. Agron. Costarricense, v. 29, p. 107-123, 2007.

CARDOSO, A. F. Fertilizante Organomineral em Batata cv, Atlantic: produtividade e crescimento e acumulo de nutrientes em diferentes safras de plantio. Paperpresentedat: Dissertação de mestrado em fitotecnia (Uberlândia, Brazil, UFU), 2014.

DONAGEMA, G. K.; CAMPOS, D. V. B.;CALDERANO, S. B.;TEIXEIRA, W. G.; VIANA, J. H. B. Manual de métodos de análise de solos. 2. ed. (Rio de Janeiro: EMBRAPA SOLOS), pp. 230, 2011. 
FAOSTAT - Food and Agriculture Organization of the United Nations 2015. www.faostat.fao.org.

FERNANDES, A. M.; SORATTO, R. P.; SILVA, B. L. Extração e exportação de nutrientes em cultivares de batata: I - macronutrientes.Rev. Bras. Ciênc. Solo, v. 32, p. 2039-2056, 2011. https://doi.org/10.1590/S010006832011000600020

FERNANDES, A. M.; SORATTO, R. P.; SILVA, B. L.; SOUZA-SCHLICK, G.S. Crescimento, acúmulo e distribuição de matéria seca em cultivares de batata na safra de inverno. Pesq. Agropec. Bras., v. 45, p. 826835, 2010. https://doi.org/10.1590/S0100-204X2010000800008

FERREIRA, D. F. SISVAR - Sistema de análise de variância. Versão 5.3, (Lavras: UFLA), 2010.

FILGUEIRA, F. A. R. 2008. Novo manual de olericultura: agrotecnologia moderna na produção e comercialização de hortaliças. Viçosa, MG: UFV. 2008. 421 p.

FONTES, P. C. R.; PEREIRA, P. R. G. Nutrição mineral do tomate para mesa. Informe agropecuário, v. 24, p. 27-34, 2003.

FONTES, P. C. R. Preparo do solo, nutrição mineral e adubação da batateira. 1 ed. (Viçosa: UFV) pp.42. 1997.

GRIMM, E. L.; HELDWEIN, A.; RADONS, S. Z.; MALDANER, I. C.; TRENTIN, G.; BOSCO, L. C. Produtividade da batata em função da irrigação e do controle químico da requeima. Rev. bras. eng. agríc. Ambiente, v. 15, p. 125-130, 2011.

GONÇALVES, M. V.; CARREON, R.; LUZ, J. M. Q.; GUIRELLI, J. E.; SILVA, P. A. R.; SILVA, M. A. D. Produção de batata. cv. Atlantic, submetida a produtos oganominerais Aminoagro. Paperpresentedat: Encontro nacional da produção e abastecimento de batata (Holambra, Brazil, ABBA). 2007.

JACKSON, R. D.; HADDOCK, J. L. Growth and mineral uptake of Russet Burbank potatoes. American Potate Journal, v. 36, p. 22-28, 1959. https://doi.org/10.1007/BF02877211

KASEKER, J. F.; BASTOS, M. B.; CONSALTER, R.; MOGOR, A. F. Alteração do crescimento e dos teores de nutrientes com utilização de fertilizante organomineral em cenoura. Rev. Ceres, v. 61, p. 964-969, 2014. https://doi.org/10.1590/0034-737X201461060011

LUZ, J. M. Q.; BITTAR, C.; QUEIROZ, A. A.; CARREON, R. Produtividade de tomate 'Débora Pto' sob adubação organomineral via foliar e gotejamento. Hortic. Bras, v. 28, p. 489-494, 2010. https://doi.org/10.1590/S0102-05362010000400019

MACEDO, M. C. M.; HAAG, H. P.; GALLO, J. R. Nutrição mineral de hortaliças.:XXI Absorção de nutrientes por cultivares nacionais de batatinha (SolanumtuberosumL.). Anais ESALQ, v. 34, p. 179-229, 1977.

MIRANDA FILHO, H. S.; GRANJA, N. P.; MELO, P. C. T. Cultura da batata.1. ed. (Vargem Grande do Sul: FAEF), pp. 68, 2003.

MESQUITA, H. A.; PÁDUA, J. G.; YURI, J. E.; ARAÚJO, T. H. Fertilização da cultura da batata. InformeAgropecuário, v. 33, p. 52-61, 2012.

NUNES, J. C. S.; FONTES, P. C. R.; ARAÚJO, E. F.; SEDIYAMA, C. Potato plant growth and macronutrient uptake as affected by soil tillage and irrigation systems. Pesq. Agropec. Bras. v. 41, p. 1787-1792, 2006. https://doi.org/10.1590/S0100-204X2006001200014 
PAULA, M. B.; FONTES, P. C. R.; NOGUEIRA, F. D. Produção de matéria seca e absorção de macronutrientes por cultivares de batata. Horticultura Brasileira, v. 4, p. 10-16, 1986.

PEDROSA, M. W.; SEDIYAMA, M. A. N.; VIDIGAL, S. M.; SALGADO, L. T.; OLIVEIRA, F.; NOBRE, M. C. Concentração de nutrientes em raízes de três cultivares de cenoura, adubadas com diferentes rates de compostos orgânicos. Revista Brasileira de Agroecologia, v. 2, p. 1145-1149, 2007.

LUZ, J. M. Q.; OLIVEIRA, G.; QUEIROZ, A. A.; CARREON, R. Aplicação foliar de fertilizantes organominerais em cultura de alface. Horticultura Brasileira, v. 28, p. 373-377, 2010. https://doi.org/10.1590/S0102-05362010000300023

OLIVEIRA A. P.; BARBOSA, A. H. D.; CAVALCANTE, L. F.; PEREIRA, W. E.; OLIVEIRA, A. N. P. Produção da batata-doce adubada com esterco bovino e biofertilizantes. Ciência Agrotécnica, v. 31, p. 17221728, 2007. https://doi.org/10.1590/S1413-70542007000600018

REIS JÚNIOR, R. A.; MONNERAT, P. H. Exportação de nutrientes nos tubérculos de batata em função de rates de sulfato de potássio. Hortic. Bras, v. 19, p. 360-364, 2001. https://doi.org/10.1590/S010205362001000300015

SOUZA, J. L.; RESENDE, P. Manual de horticultura orgânica. 1 ed. (Viçosa: Aprenda fácil), pp. 564, 2003.

SOUSA, D. G.; LOBATO, E. Cerrado: correção do solo e adubação. 2 ed. (Planaltina: EMBRAPA Cerrados) pp.416, 2004.

SORATTO, R. P.; FERNANDES, A. M.; SOUZA-SCHLICK, G. D. Extração e exportação de nutrientes em cultivares de batata: II - micronutrientes. Rev. Bras. Ciênc. Solo, v. 35,p. 2057-2071, 2011. https://doi.org/10.1590/S0100-06832011000600021

TEIXEIRA, W. G. Biodisponibilidadde de fósforo e potássio de fertilizantes mineral e organomineral. Paperpresentedat: Dissertação de mestrado em fitotecnia (Uberlândia, Brazil, UFU), 2013.

YORINORI, G. T. Curva de crescimento e acúmulo de nutrientes pela cultura da batata cv. 'Atlantic'. Paper presente dat: Dissertação de mestrado em fitotecnia (Piracicaba, Brazil, ESALQ),2003.

ZOBIOLE, L. H. S.; CASTRO, C.; OLIVEIRA, F. A.; OLIVEIRA JUNIOR, A. Marcha de absorção de macronutrientes na cultura do girassol. R. Bras. Ci. Solo, v. 34, p. 425-433, 2010.

https://doi.org/10.1590/S0100-06832010000200016 